\title{
The Vannamei Prawns Aquaculture based Coastal Carrying Capacity in The Coast Areas of Indramayu
}

\author{
Dwi Putri Wigiani ${ }^{1}$, Bambang Widigdo ${ }^{2}$, Kadarwan Soewardi ${ }^{2}$, Taryono $^{2}$, Aldiano \\ Rahmadya $^{3}$ \\ ${ }^{I}$ Postgraduate Students of Coastal and Marine Resources Management, Faculty of Fisheries and Marine \\ Science, IPB University. ${ }^{2}$ Department of Aquatic Resources Management, Faculty of Fisheries and \\ Marine Science University, IPB ${ }^{3}$ Limnology Research Center, LIPI Bogor Indonesia
}

Corresponden Email : dputriwigiani@gmail.com

Received : 26 November 2019; Accepted: 29 December 2019

\begin{abstract}
Dwi Putri Wigiani, Bambang Widigdo, Kadarwan Soewardi, Taryono, and Aldiano Rahmadya. 2019. The Vannamei Prawns Aquaculture based Coastal Carrying Capacity in The Coast Areas of Indramayu. Aquacultura Indonesiana, 20(2) : 109 - 116. Theutilization of coastal area nowadays is commonly used for vannamei prawns aquaculture, either with traditional technology "plus" and intensive technology. The regency of Indramayu is a district in which coastal regions are now utilized to vannamei prawns aquaculture. The uncontrolled development of this aquaculture farming will cause an impact on the surrounding environment, and will eventually threaten other environment sectors in the coastal areas of Indramayu. This research was aimed to calculate the carrying capacity of the coastal area in sub-district of Indramayu. The analysis of the carrying capacity used the approach of Rakocy and Allison (1981) which stated that waste water recipient amounts to 100 times the volume of waste, in addition to using the assumptions developed by Boyd and Musig (1992) stated that the maximum feed in prawn ponds, the volume of waters using a model developed by Widigdo and Pariwono (2003). Water quality parameters used Total Suspended Solid (TSS). The measurement results of the carrying capacity amounted to $83.50 \mathrm{Ha}$. Based on spatial analysis, the area of prawn ponds in sub-district of Indramayu was $890 \mathrm{Ha}$, when compared to the carrying capacity analysis based on TSS, the shrimp pond area in Indramayu District has over-exceeded the carrying capacity. In conclusion, the carrying capacity of the coastal area for vannamei prawn aquaculture was $83.50 \mathrm{Ha}$.
\end{abstract}

Keywords: coast, carrying capacity, TSS, vannamei.

\section{Introduction}

Coastal and marine areas have a strategic and important meaning in the aspect of the economic development of the nation. Some parts of coastal and marine have potential that can be more developed and utilized in accordance with its characteristics of their habitat and resources, following the direction of the Indonesian government's policy which is nowaday has oriented to the maritime sector.

One of these strategic functions is aquaculture. Over the past three decades, aquaculture is the main alternative that can be implemented in order to supply the food needs of the global community after the decline and the stagnation of marine fishing and the increasing demand for fishery products in regional and global markets (Ottinger et al. 2016). One of the aquaculture commodities that have high economic value and high export demanded by many countries is vannamei prawn (L.vannamei) (Yasin 2013).

Indonesia has a potential area of aquaculture in brackish water for around 2.9 million hectares, with a utilization rate of around 715846 hectares or $24.15 \%$ (DJPB 2016). The Indramayu Regency in West Java Province with a coast length of about $114 \mathrm{~km}$ is one of the prawn 
production centers. Research data from

Indramayu Regency had a pond area of $15080 \mathrm{Ha}$, while in 2016, it developed to become 22514.07 Ha (DKP Kab. Indramayu 2017).

The increase of aquaculture area land and the changes in the system of vannamei prawn aquaculture can increase the ecological pressure on the coastal areas of Indramayu Regency and surrounding areas, so that the development of vannamei prawn culture in coastal areas should be adjusted to the carrying capacity of the environment.

The concept of carrying capacity is to focus based on ecological carrying capacity. Ecological carrying capacity according to Supriharyono (2002) is the maximum level of use the ecosystem ar some area, both about how many of the amount or activities accommodated in it, before the declining quality of the area. The purpose of this study was to calculate the carrying capacity in the coastal area of Indramayu Regency.

\section{Material and Methods}

The study was conducted in April August 2018, located in 4 villages of vannamei prawn production centers, there are Pabean Udik, Karangsong, Singaraja and Singajaya villages. These villages have
Suwargana (2002) stated that, in 2000, an area with a total land area of $690 \mathrm{Ha}$ (77\%) of the total land area in Indramayu Regency that is used for vannamei prawn aquaculture for about $890 \mathrm{Ha}$ (Figure 1). Water quality sampling locations is based on the representation of vannamei prawn aquaculture activities that can affect the quality of coastal waters to 4 stations (Figure 1).

The determination of the sampling location needed for the data based on the estimation of the distribution (dispersion) of the residue results of vannamei prawn aquaculture to the sea. This residue dispersion is based on the assumption that the sea is in a steady-state (not affected by turbulence and large ocean currents). The location of water sampling is carried out in estuaries and in the sea which is estimated as an area affected by vannamei prawn aquaculture activities in Indramayu Regency. The estuary area is assumed to be the input point for aquaculture and marine discharge as the point for mixing cultivation and seawater discharges. Estimation of estuary water is $500 \mathrm{~m}-1 \mathrm{~km}$ from the edge of the coastal area and for seawater samples taken more than $1 \mathrm{~km}$ from the edge of the coastal area towards the sea (Darmawan dan Masduqi 2014).

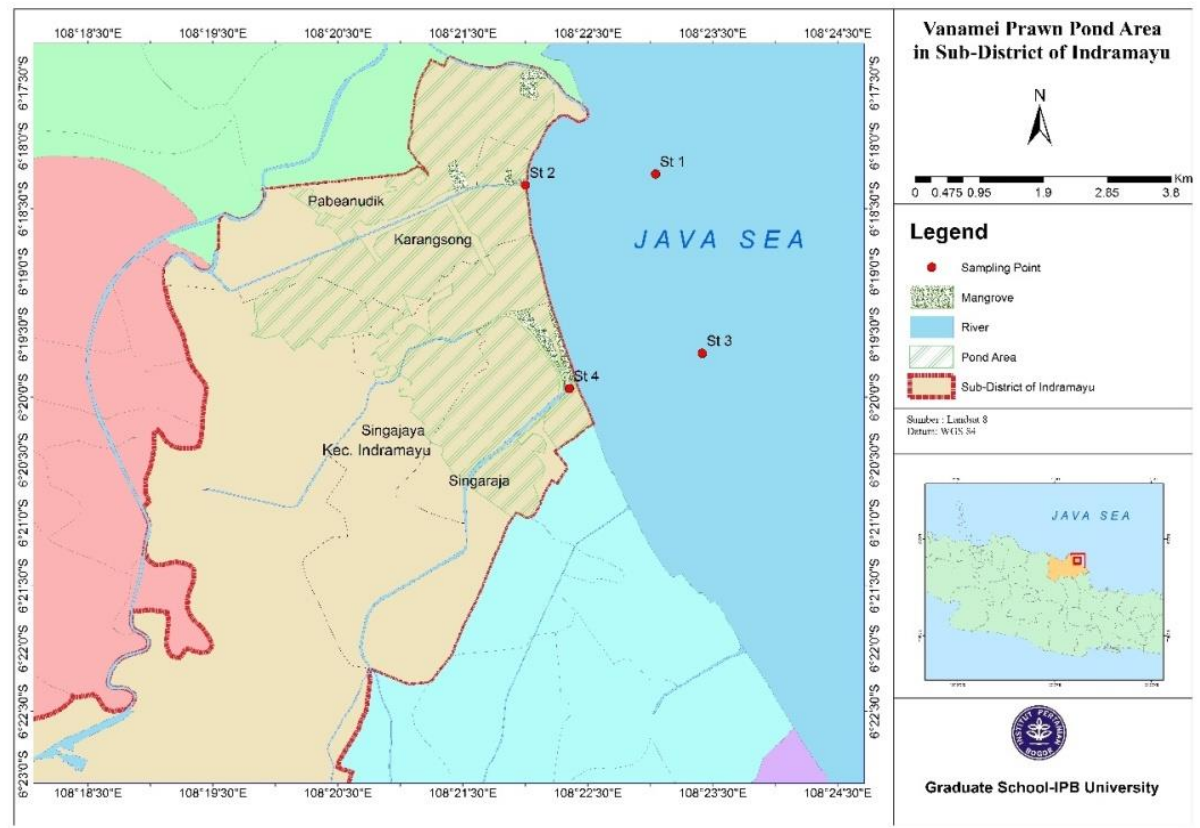

Figure 1 The sampling location of water quality in many vannamei prawn ponds in sub-district of Indramayu 
Parameters measured directly in the field (in-situ) include turbidity, temperature, $\mathrm{DO}, \mathrm{pH}$, and salinity. The parameters analyzed in the laboratory as ex-situ are TSS, COD, ammonia, and phosphate. Turbidity is the depth of the Secchi disk which is dipped to the water column where the black color of Secchi disk is first not seen. Salinity measured using a refractosalinometer, $\mathrm{pH}$ and temperature are measured using a $\mathrm{pH}$ meter, and $\mathrm{DO}$ is measured using a DO meter.

\section{Data Analysis}

Data analysis in this study includes calculation of pollution index (PI), carrying capacity analysis.

\section{Pollutant Index (PI)}

PI value is a description of the water pollution level. Assessing water quality status by PI refers to the Decree of the Ministry of Environment of Indonesia (Kepmen LH) No. 115 / 2003 concerning Status of Water Quality (Table 5). This index is used to determine the level of pollution relative to permitted water quality parameters. Water quality parameters that are permitted or referred to as quality standards in this study were referred to the Decree of the Ministry of Environment of Indonesia No.51 / 2004 concerning Sea Water Quality Standards for Marine Biota. The formula for calculating the Pollution Index is:

$$
I P_{j}=\sqrt{\frac{\left(C_{i} / L_{i j}\right)_{M}^{2}+\left(C_{i} / L_{i j}\right)_{R}^{2}}{2}}
$$

Where,

$$
\begin{aligned}
I P_{j}= & \begin{array}{l}
\text { Pollution index for all } \\
(\mathrm{j})
\end{array} \\
C_{i}= & \begin{array}{l}
\text { The concentration of } \\
\text { the (i) as water quality }
\end{array} \\
& \text { parameters measured } \\
L_{i j}= & \text { The concentration of } \\
& \text { the (i) as water quality } \\
& \text { parameters listed in } \\
& \text { the (j) as quality } \\
& \text { standard (quality }
\end{aligned}
$$

standard for marine biota)

$\left(C_{i} / L_{i j}\right)_{M}=\underset{C_{i} / L_{i j}}{\text { Maximum value of }}$

$\begin{aligned}\left(C_{i} / L_{i j}\right)_{R}= & \text { Average value of } \\ & C_{i} / L_{i j}\end{aligned}$

Provisions that must be considered in calculating PI values are:

i. Calculate the value of $C_{i} / L_{i j}$ for each parameter at each sampling location that will be measured. According to Nomerow (1991), the increased value of the parameter concentration states that the level of pollutions has increased:

$$
\left(C_{i} / L_{i j}\right)_{\text {measurement value }}=C_{i} / L_{i j}
$$

ii. Increasing pollution caused by decreased concentration of some parameters such as DO parameters, the theoretical value or practical maximum value $\left(C_{i m}\right)$ which is a saturated DO value is used to determine the new value. Calculation of $\left(C_{i} / L_{i j}\right)_{\text {recent }}$ has a new formula :

$$
\left(C_{i} / L_{i j}\right)_{\text {recent }}=\frac{C_{i m}-C_{i(\text { measurement value })}}{C_{i}-L_{i j}}
$$

iii. If a parameter with a default value $\left(L_{i j}\right)$ which has a range from minimum to maximum, then the value must determine $\left(L_{i j}\right)_{\text {average }}$ obtained from:

$\left(C_{i} / L_{i j}\right)_{\text {recent }}=\frac{L_{i j(\min )}-L_{i j(\max )}}{2}$

- If $C_{i} \leq\left(L_{i j}\right)_{\text {average }}$

$$
\left(C_{i} / L_{i j}\right)_{\text {recent }}=\frac{\left[C_{i}-\left(L_{i j}\right)_{\text {recent }}\right]}{\left[\left(L_{i j}\right)_{\text {min }}-\left(L_{i j}\right)_{\text {average }}\right]}
$$

- If $C_{i} \geq\left(L_{i j}\right)_{\text {average }}$

$$
\left(C_{i} / L_{i j}\right)_{\text {recent }}=\frac{\left[C_{i}-\left(L_{i j}\right)_{\text {average }}\right]}{\left[\left(L_{i j}\right)_{\max }-\left(L_{i j}\right)_{\text {average }}\right]}
$$

iv. If the measurement value is greater than 1 , the value used is the new 
v. $\left(C_{i} / L_{i j}\right)_{\text {recent }}$ with the following formula:

$$
\left(C_{i} / L_{i j}\right)_{\text {recent }}=1+P \log \left(C_{i} / L_{i j}\right)_{\text {measurement }}
$$

$\mathrm{P}$ is a constant as a standard value for comparison, in common, the value of $\mathrm{P}$ is used as 5 adjusted to the results of the desired requirements for an allotment. The relationship of the pollution index value with the water quality standard is presented in Table 1.

Table 1. Classification of water quality categories according to Pollution Index (Ministry of Environment No. 115 / 2003)

\begin{tabular}{ll}
\hline Score of Pollution Index & Category \\
\hline $0 \leq \mathrm{IP}_{\mathrm{j}} \leq 1.0$ & Pass the quality standard (good condition) \\
$1.0<\mathrm{IP}_{\mathrm{j}} \leq 5.0$ & Lightly polluted \\
$5.0<\mathrm{IP}_{\mathrm{j}} \leq 10$ & Medium polluted \\
$\mathrm{IP}_{\mathrm{j}}>10$ & Heavily polluted \\
\hline
\end{tabular}

\section{Analysis of Carrying Capacity in Coastal Area}

Carrying capacity is a basic concept developed for the sustainable management of natural resources and the environment. This concept was developed to prevent damage or degradation of natural resources and the environment (Soewardi 2017). The ability of waters to accommodate waste/effluent from the residue of vannamei prawn aquaculture activities needs to be known because it can be a representative of the carrying capacity of the area.

Assumptions used to estimate the natural carrying capacity of waters are as follows:

1 Rakocy dan Allison (1981) who stated that the amount of wastewater received was 100 times the volume of waste. Mathematically, it can be written as follows :

$\mathrm{V}$ waters $\geq 100 \mathrm{~V}$ residue of pond

2 Boyd dan Musig (1992) stated that the maximum feed-in prawn ponds, in order to make its sustainability maintained by the following:

- $\quad$ Amount of feed 100-150 kg / ha / day (intensive technology)

- Maximum feed: 4th month (nearing harvest)

- The dose of the feed is given to prawn that have reached 30-35 gr / individual in percentage is 2 $2.5 \%$
- Prawn biomass at this time is 4 7.5 tons / $\mathrm{Ha}$

- Substitution of pond water at that time as much as $10 \%$ / day

Based on these principles and assumptions, to calculate the carrying capacity of coastal waters, first, it necessary to know the volume of coastal waters that will receive the waste and the volume released by one hectare of ponds. The relationship is used to determine the volume of waters (Widigdo dan Pariwono 2003) through the calculation of the volume of coastal waters in order to determine the maximum area for sustainable environment of pond area that can be built. The formula developed to determine the volume of coastal waters and illustration of Figure 3 for simplification is as follows:

$$
\mathrm{V}_{0}=0.5 \text { hy }\left(2 \mathrm{x}-\frac{\mathrm{h}}{\operatorname{tg} \theta}\right) \ldots \ldots
$$

Where,

$\mathrm{Vo}=$ Available of seawater volume $\left(\mathrm{m}^{3}\right)$ or water volume.

$\mathrm{h}=$ Local tidal range $(\mathrm{m})$.

$\mathrm{y}=$ width of the pond area that is parallel to the coastline $(\mathrm{m})$.

$\theta=$ the slope of the seafloor (degree).

$\mathrm{x}=$ Distance from the coastline (low tide time) to the location of seawater intake for the purposes of the pond $(\mathrm{m})$, where the water depth ranges from $2 \mathrm{~m}$ 
If the frequency ( $\mathrm{f}$ ) of the tides is $\mathrm{f}$ times a day, the total water volume $\left(\mathrm{V}_{\mathrm{OT}}\right)$ in diluting the waste becomes:

$$
V_{0 T}=f x V_{0 \ldots \ldots(2)}
$$

As the volume of water has been known $\left(\mathrm{V}_{\mathrm{OT}}\right)$, the volume of waste that can be accommodated by water is one-hundredth of the volume of water stated in the formula as follows

$$
\mathrm{VL}=\frac{V_{0 T}}{100} \ldots \ldots
$$

\section{Result}

The results of measurements of several water quality parameters at four stations showed for physical parameters, water temperature ranges from $28.4-31{ }^{\circ} \mathrm{C}$, salinity ranges from 26 to $32 \mathrm{ppt}$, Total Solid Suspended (TSS) at the highest station 3 when compared to other stations at $124 \mathrm{mg} / \mathrm{L}$, the brightness value ranges from $0.56-1.2$ meters.

While the chemical parameters of $\mathrm{pH}$ values ranged from 6.5 to $7.4, \mathrm{NH} 3$ values ranged from 0.025 to $0.166 \mathrm{mg} / \mathrm{L}$ with the largest values being at station 4, the measured phosphate levels at the four stations ranged from 0.016 to $0.103 \mathrm{mg} / \mathrm{L}$, COD values ranged from 46.72 to $58.74 \mathrm{mg}$ / $\mathrm{L}$ and DO values range from $5.92-6.21$ $\mathrm{mg} / \mathrm{L}$.

\begin{tabular}{|c|c|c|c|c|c|c|c|c|}
\hline $\begin{array}{l}\mathrm{N} \\
\mathrm{o}\end{array}$ & Parameter & $\begin{array}{l}\text { Un } \\
\text { it }\end{array}$ & $\begin{array}{c}\text { Env.Quality } \\
\text { Standard } \\
\text { (Kepmen LH } \\
\text { No. 51 / } \\
\text { 2004) }\end{array}$ & $\begin{array}{c}\text { Standard } \\
\text { Quality of } \\
\text { Residual } \\
\text { Aquaculture } \\
\text { Waste GAA } \\
2014\end{array}$ & $\begin{array}{c}\text { Station } \\
1 \\
\text { (Sea) }\end{array}$ & $\begin{array}{c}\text { Station } \\
2 \\
\text { (Estuary } \\
\text { ) }\end{array}$ & $\begin{array}{c}\text { Station } \\
3 \\
\text { (Sea) }\end{array}$ & $\begin{array}{c}\text { Station } \\
4 \\
\text { (Estuary } \\
\text { ) }\end{array}$ \\
\hline 1 & $\mathrm{pH}$ & - & $7-8.5$ & $6-9.5$ & 7.2 & 6.7 & 6.5 & 7.4 \\
\hline 2 & $\begin{array}{l}\text { Temperat } \\
\text { ure }\end{array}$ & ${ }^{\circ} \mathrm{C}$ & $28-32$ & & 28.4 & 28.6 & 31 & 30.8 \\
\hline $\begin{array}{l}3 \\
4\end{array}$ & Salinity & $\begin{array}{l}\text { ppt } \\
\mathrm{mg}\end{array}$ & $33-34$ & $\leq 50$ & 31 & 26 & 32 & 27.3 \\
\hline $\begin{array}{l}5 \\
6\end{array}$ & $\begin{array}{l}\text { TSS } \\
\text { turbidity }\end{array}$ & $\begin{array}{l}/ 1 \\
\mathrm{~m} \\
\mathrm{mg}\end{array}$ & $\begin{array}{r}20-80 \\
3\end{array}$ & & $\begin{array}{r}16 \\
1.2\end{array}$ & $\begin{array}{r}35 \\
1\end{array}$ & $\begin{array}{r}124 \\
0.56\end{array}$ & $\begin{array}{r}25 \\
0.85\end{array}$ \\
\hline 7 & $\mathrm{NH}_{3}$ & $\begin{array}{l}/ 1 \\
\mathrm{mg}\end{array}$ & 0.3 & $\leq 0.5$ & 0.025 & 0.053 & 0.134 & 0.166 \\
\hline 8 & Phosphate & $\begin{array}{l}/ 1 \\
\mathrm{mg}\end{array}$ & 0.015 & & 0.016 & 0.103 & 0.026 & 0.055 \\
\hline 9 & COD & /l & $200^{\mathrm{a}}$ & $\geq 4$ & 46.72 & 54.02 & 58.74 & 48.87 \\
\hline & DO & $/ 1$ & $>5$ & & 6.21 & 6.14 & 5.92 & 6.2 \\
\hline
\end{tabular}

Tabel 2 . The result of water quality measurement

Based on the measurement results above parameters can be calculated the value of the Pollution Index that refers to Kep.Men LH No. $115 / 2003$. The results showed that the coastal waters of the Indramayu Regency both in the estuary and in the sea mildly polluted $\left(1,0<\mathrm{IP}_{\mathrm{j}} \leq 5,0\right)$ 
Table 3. The result of water pollutant index

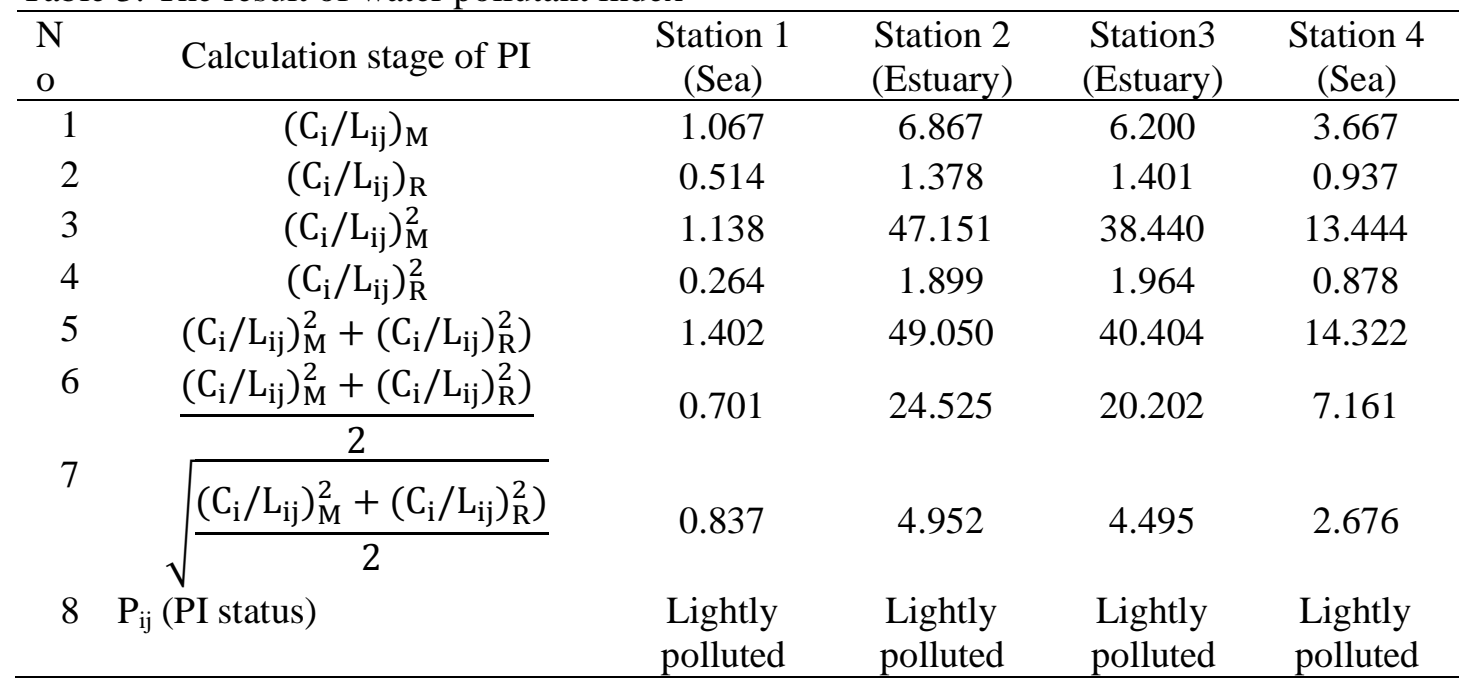

Source: primary data processing 2018

\section{Discussion}

The results of the pollution index analysis show that the waters in the subdistrict of Indramayu are classified as slightly polluted with a value of $1,0<\mathrm{IP}_{\mathrm{j}} \leq$ 5,0 . When assessing from the single parameters of the pollution index, the values of some parameters are still below of the quality standard, i.e. $\mathrm{pH}$, temperature, salinity, brightness, and DO, while there are several parameters that have exceeded the quality standard such as TSS and phosphate. The highest TSS value of 124 $\mathrm{mg} / \mathrm{L}$ in station 3 is located in the sea area. TSS is one of the parameters used to determine the quality of water, a high TSS value indicates a high level of pollution and inhibits the penetration of light into the water, resulting in disruption of the photosynthesis process of aquatic biota (Parwati, 2014). Measurements are conducted at low tide so that water input from land strongly influences the value of the TSS, Andriyono (2010) stated that measuring tides is the most important parameter in flow circulation along estuary areas, Triatmodjo (1999) stated that suspended sediments will be affected in their shift along the estuary, which will move upstream at high tide and downstream at low tide.

Another parameter that has a high enough value is the phosphate-based on the standard quality of phosphate levels that can be tolerated is $0.015 \mathrm{mg} / \mathrm{L}$ while the measurement results range from 0.016 to $0.103 \mathrm{mg} / \mathrm{L}$. The highest phosphate value is at station 2. The high phosphate value caused by the input of run off the upstream area where there are many agricultural activities and residential settlements. According to Supardi (1994) with the presence of residential housing, agricultural and plantations, it is possible to enter domestic waste, especially in the form of phosphate. Sanusi (2006) stated that the main source of phosphate comes from the mainland, which is weathering rocks that enter the sea mainly through the river.

Coastal carrying capacity in the Indramayu Regency, based on the results of the calculation of the water volume showed has not to exceed the carrying capacity, which is equal to $8349867 \mathrm{~m}^{3}$. Rakocy dan Allison (1981) stated that the maximum volume of waste ( $\mathrm{V}$ waste) that can be collected in waters is one-hundredth of the total volume of water $\left(\mathrm{V}_{\mathrm{OT}}\right)$ i.e. $83499 \mathrm{~m}^{3} /$ day and is the result of a $10 \%$ change in pond volume. The detailed explanation is that after knowing the pond waste volume that can be supported is $83499 \mathrm{~m}^{3}$ thus the maximum pond volume is $834987 \mathrm{~m}^{3}$. The average depth of a pond in the sub-district of Indramayu is $1 \mathrm{~m}$. It is known that the maximum area of a pond that can be supported is 83.50 Ha. Boyd dan Musig (1992) who stated that the maximum feed that can be given so that prawn ponds while maintaining its sustainability is $150 \mathrm{~kg} /$ day with a percentage of $2 \%-2.5 \%$ of prawn 
biomass when approaching harvest so it can be assumed that prawn productivity is 6 $-7.5 \mathrm{ton} / \mathrm{Ha} / \mathrm{MT}$.

Based on these assumptions, the water capacity at the coast of Indramayu Regency is able to accommodate pond waste from prawn biomass between $6-7.5$ ton $/ \mathrm{Ha} / \mathrm{MT}$ which is intensively maintained at $83.50 \mathrm{Ha}$ pond (water column). ). The pond area as a whole consists of water and land columns that function as locations for supporting facilities such as embankments, footpaths, guard houses, etc. with a comparison between the water column and land, in general, is $60 \%$ : 40\%. Farm ponds that can be cultivated intensively in Indramayu Regency based on this comparison are 139.16 Ha. The area of prawn ponds in Indramayu Regency is 90 890 Ha with average productivity in the last five years of around 21000 tons / year with 3 (three) growing seasons (DKP Kab. Indramayu 2017). This means that the production of biomass produced in 1 hectare of ponds in Indramayu District is 23.6 tons / Ha / year or 7.8 tons / Ha / MT. Production produced from ponds is 139.16 $\mathrm{Ha}$ in ideal conditions based on the calculation of the availability of water volume is 626.24 tons / MT or 1878.72 tons / year, therefore, the coastal area of Indramayu Regency is relatively good condition despite the area of the sustainable pond area and the amount of production are still ideal beyond the carrying capacity of its waters.

\section{Acknowledgment}

We would like deliver thank you to Human Resources Development Agency Ministry of Marine Affairs and Fisheries of Indonesia and the Marine and Fisheries Office of Indramayu Regency, fisheries instructors, vannamei prawn farmers, and the community of sub-district Indramayu who have provided us the information and support this research.

\section{References}

[DJPB] Direktorat Jenderal Perikanan Budidaya. 2016. Aquaculture statistics pocketbook year of 2015. Jakarta (ID). Ministry of Marine Affairs and Fisheries

[KLH] Kementrian Lingkungan Hidup. 2003. Regulation of the Ministry of Environment of Indonesia No.115 of 2003 concerning Status of Water Quality. Jakarta (ID): KLH. P. 9-15.

[KLH] Kementrian Lingkungan Hidup. 2004. Regulation of the Ministry of Environment of Indonesia No.51 Tahun 2004 concerning Sea Water Quality Standards. Jakarta (ID): KLH. attachment III. p. 1-2

Andriyono S. 2010. Estuary Porong Status Based on Klorofil-A Index and Total Sedimen Solid (TSS). Jurnal Ilmiah Perikanan dan Kelautan Vol. 2 (2):171 177

Boyd CE, Musig Y. 1992. Shrimp pond effluents. Proceedings Special Session on Shrimp Farming. Wyban JA.ed. Baton Rouge, LA: World Aquaculture Society. p.166 -181

Darmawan H, Masduqi A. 2014. Index of seawater pollution in the North Coast of Tuban with TSS parameters and nonmetallic chemistry. Jurnal Teknik Pomits. 3(1): 16 - 20.

Ottinger M, Clauss K, Kuenzer C. 2016. Aquaculture: Relevance, distribution, impacts and spatial assessments - A review. J. Ocean \& Coastal Management. 119 (2016): 244- 266.

Parwati E. 2014. Dynamics Analysis of TSS (Total Suspended Solid) Fluctuations along the Muara-Laut Watershed in Berau Waters in East Kalimantan. Seminar Nasional Penginderaan Jauh. p. $662-670$.

Rakocy JE, Allison R. 1981. Evaluation of closed recirculating systems for the culture of tilapia aquatic macrophytes. Proceedings of the bio-engineering symposium for fish culture. Bethesda, Md. Fish Culture Section, American Fisheries Society. p. 296-307

Supriharyono. 2002. Management of coastal resources in the tropics. Jakarta (ID): PT. Gramedia.

Suwargana N. 2002. Conformity of conventional ponds through land quality and product testing with the help of remote sensing data and GIS. [tesis]. Bogor (ID): Institut Pertanian Bogor.

Triatmodjo B. 1999. Coastal Engineering: 2nd edition. Yogyakarta. Beta Offset

Widigdo B, Pariwono J. 2003. Carrying capacity of waters on the North Coast of West Java for shrimp farming (Case 
studies in Subang District, Jakarta Bay, and Serang). Jurnal Ilmu-ilmu Perairan dan Perikanan Indonesia 10(1):10-17.

Yasin M. 2013. Economic analysis of shrimp pond business based on a land area in Parigi Moutong Regency, Central Sulawesi Province. Jurnal Ilmiah AgrIBA No. 2. p.15 - 45 . 